\title{
Pitkäaikaissäilytys kryomenetelmällä
}

\author{
Anna Nukari ${ }^{1)}$, Saija Rantala ${ }^{1)}$ ja Marjatta Uosukainen ${ }^{1)}$ \\ ${ }^{1}$ MTT Kasvintuotannon tutkimus, Taimistotutkimus, Antinniementie 1, 41330 Vihtavuori, \\ anna.nukari@mtt.fi
}

\section{Tiivistelmä}

Kryosäilytys eli kylmäsäilytys nestetypessä $\left(-196^{\circ} \mathrm{C}\right.$ ) tai sen kaasufaasissa (alle $-150^{\circ \circ} \mathrm{C}$ ) soveltuu hyvin kasvigeenivarojen tehokkaaseen, edulliseen ja luotettavaan pitkäaikaissäilytykseen. Se on verraten uusi ja jatkuvasti kehittyvä menetelmä. Erityisesti kasvullisesti lisättävillä ja taudinaroilla kasvilajeilla kylmäsäilytys on varteenotettava vaihtoehto perinteisille geenivarojen pitkäaikaissäilytysmenetelmille. Kryosäilytyksen avulla geenivaroja voidaan säilyttää pienessä tilassa eikä talletettuihin aineistoihin tarvitse pakastusvaiheen jälkeen kajota muulloin kuin aineistoja käytettäessä. Tämä vähentää ylläpidossa sattuvien saastuntojen tai inhimillisten virheiden aiheuttamia riskejä sekä ylläpitokustannuksia.

Kylmänkestävät kasvilajikkeet ovat karaistumiskykynsä takia teoriassa helpompia kylmäsäilytettäviä kuin leudon seudun lajikkeet. Emokasvien kylmänkestävyyttä voidaan myös lisätä esikäsittelyillä ennen varsinaista kylmäsäilytystä. Käytännössä kylmäsäilytyksessä käytettävät menetelmät on kuitenkin optimoitava erikseen kullekin kasvilajille.

Kylmäsäilytyksen soveltaminen puutarhakasveille aloitettiin MTT, Kasvintuotannon tutkimus Laukaassa vuonna 2004. Alkuvaiheen menetelmäkokeilujen jälkeen käytettäväksi valittiin muunneltu pisara-vitrifikaatio-menetelmä, joka optimoitiin ensin vadelmalle ja mansikalle. Menetelmä perustuu solukkoviljelyllä tuotettujen silmujen tai versonkärkien säilytykseen ja se on käytettävissä laajasti eri kasvullisesti lisättäville kasveille riippumatta niiden kylmäkaraistumiskyvystä. Vitrifikaatiossa soluissa oleva vesi vaihdetaan jäänsuoja-aineisiin käsittelemällä kasvupisteitä vitrifikaatioliuoksin. Tällöin solujen ja soluvälien neste muuttuu niin viskoosiseksi, että kidemäistä jäätä ei synny. Esikäsittelyjen jälkeen solukkoviljelty kasvimateriaali jäädytetään asettamalla kasvupisteet folioliuskan päälle pieneen pisaraan vitrifikaatioliuosta ja sulkemalla folioliuska pieneen putkeen, joka upotetaan suoraan nestemäiseen typpeen ja siirretään säilytykseen kryotankkiin. Aikanaan, sulatuksen jälkeen jäänsuoja-aineet pestään pois ja versonkärjet siirretään kasvamaan ravintoalustalle.

MTT:ssa vuonna 2006 käynnistyneen tutkimushankkeen tavoitteena on kylmäsäilytysmenetelmien kehittäminen ja kasvigeenivarojen onnistunut pitkäaikaissäilytys kryomenetelmien avulla. Hankkeella pyritään MTT:n hallussa olevan laajan geenivara-aineiston säilyttämiseen mahdollisimman turvallisesti ja kustannustehokkaasti. Kryosäilytyksen käyttöönotolla vähennetään jatkossa peltokokoelmien ja solukkoviljelmien lukumäärää ja säilytyskustannuksia. Hankkeen aikana MTT:een on perustettu pysyvä kylmäsäilytyskokoelma (kryopankki). Kansallisten geenivarojen pikäaikaissäilytys kryopankkiin on aloitettu tallettamalla kasvigeenivaraohjelman humalakokoelmaa sekä MTT Piikkiön vadelmakokoelmaa. Työ on käynnissä myös mm. mansikoilla, herukoilla ja Prunus-lajeilla. Perunan kryosäilytys on kokeiluasteella.

\section{Asiasanat}

Geenivarat, herukka, humala, kylmäsäilytys, mansikka, nestetyppi, peruna, vadelma, vitrifikaatio 


\section{Johdanto}

Kryosäilytys eli kylmäsäilytys nestetypessä $\left(-196^{\circ} \mathrm{C}\right.$ ) tai sen kaasufaasissa (alle $-150^{\circ \circ} \mathrm{C}$ ) soveltuu hyvin kasvigeenivarojen tehokkaaseen, edulliseen ja luotettavaan pitkäaikaissäilytykseen. Se on verraten uusi ja jatkuvasti kehittyvä menetelmä. Erityisesti kasvullisesti lisättävillä ja taudinaroilla kasvilajeilla kylmäsäilytys on varteenotettava vaihtoehto perinteisille geenivarojen pitkäaikaissäilytysmenetelmille. Kasvullisesti lisättävien kokoelmien ylläpidossa perinteisiä pitkäaikaissäilytysmenetelmiä ovat olleet mm. avomaasäilytys ja solukkolisäys. Kryosäilytyksen käyttöönotolla vähennetään jatkossa peltokokoelmien ja solukkoviljelmien lukumäärää ja säilytyskustannuksia. Avomaasäilytyksessä kasvintuhoojien, fysiologisten vaurioiden sekä mekaanisten vioitusten vaara on suuri. Erityisen ongelmallisia ovat helposti leviävät virus-, bakteeri- ja sienitaudit. Esimerkiksi Prunus- ja Rubus-lajeilla suuren ongelman muodostavat siitepölyn välityksellä leviävät virukset, jotka voivat nopeasti saastuttaa puhdistetun aineiston kenttäsäilytyksessä.

Kansainvälisesti laadukkaassa geenivaratyössä edellytetään, että geenipankeissa säilytettävä ja niistä toimitettava aineisto on kasvintuhoojista vapaata ja testattua. IPGRI:n (International Plant Genetic Resources Institute) kansainvälisten ohjeiden mukaan kasvullisesti lisättävät kasvit tulisi säilyttää kryosäilytyksessä aina kun se on mahdollista. In vitro- ja kenttäkokoelmat palvelisivat lähinnä kokoelmien aktiivista käyttöä (Reed ym. 2004).

Kryosäilytyksen avulla talletettuihin aineistoihin ei tarvitse kajota muulloin kuin aineistoja käytettäessä joten geenivaroja voidaan säilyttää pienessä tilassa ilman työlään ylläpidon aikana sattuvien saastuntojen tai inhimillisten virheiden aiheuttamia riskejä. Menetelmän avulla voidaan vähentää myös kokoelmien ylläpitokustannuksia. Yhdysvaltalaisen arvion mukaan yhden hedelmäpuukannan säilytys avomaalla maksaa noin 50-75 dollaria vuodessa. Vastaava kustannus kryosäilytyksellä on aineiston pakastamisen yhteydessä syntyvien noin 50 dollarin alkukustannusten jälkeen noin 1 dollari vuodessa (Forsline 2000).

Kylmäsäilytyksen soveltaminen puutarhakasveille aloitettiin MTT Kasvintuotannon tutkimuksessa Laukaassa vuonna 2004, jolloin "Suomen kansallisen kasvigeenivaraohjelman toimeenpano" hankkeeseen kuuluva osatutkimus "Testattujen puutarhakasvien pitkäaikaisvarastointi kylmäsäilytyksen avulla” -hanke, alkoi. Tässä vuosina 2004-2006 toteutetussa tutkimushankkeessa selvitettiin kryosäilytyksen ja eri kryosäilytystapojen yleistä soveltuvuutta käytettäviksi puutarhakasveilla MTT:ssa.

Vuonna 2006 käynnistyneessä ”Kylmäsäilytystekniikan soveltaminen kasvullisesti lisättävien kasvien geenivarojen pitkäaikaissäilytyksessä” -hankkeessa avainsisältönä on kylmäsäilytysmenetelmien kehittäminen ja kasvigeenivarojen onnistunut pitkäaikaissäilytys kryomenetelmien avulla. Hankkeella pyritään mahdollistamaan MTT:n hallussa olevan laajan geenivara-aineiston säilyttäminen mahdollisimman turvallisesti ja kustannustehokkaasti. Osatavoitteita ovat kylmäsäilytysohjeiden ja lisäysmenetelmien optimoiminen säilytettäville aineistoille siten, että menetelmä soveltuu mahdollisimman monelle kulloinkin tutkittavan kasviryhmän kasville. Lisäksi tavoitteena on optimoida menetelmiä ja laatia tarkemmat menettelyohjeet myös ns. vaikeille kasveille, joille yleisempi menettely ei sovellu.

\section{Aineisto ja menetelmät}

Kylmänkestävät kasvilajikkeet ovat karaistumiskykynsä takia teoriassa helpompia kylmäsäilytettäviä kuin leudon seudun lajikkeet. Emokasvien kylmänkestävyyttä voidaan myös lisätä erilaisin esikäsittelyin, mutta käytännössä kylmäsäilytyksessä käytettävät menetelmät on kuitenkin optimoitava erikseen kullekin kasvilajille ja ongelmallisissa tapauksissa myös eri lajikkeille.

Kylmäsäilytysmenetelmät voidaan jakaa kahteen ryhmään: perinteisiin jäädytysmenetelmiin ja hiljattain kehiteltyihin vitrifikaatio- tai dehydraatiomenetelmiin. Perinteisiä jäädytysmenetelmiä ovat kasvinosan upotus suoraan nestetyppeen, kasvinosan jäädyttäminen vaiheittain $-20^{\circ} \mathrm{C}$ :sta $-196^{\circ} \mathrm{C}$ :een tai kasvinosan jäädyttäminen $0,2-1,0^{\circ} \mathrm{C} /$ minuutti noin $-40^{\circ} \mathrm{C}$ :een, minkä jälkeen näyte upotetaan nestetyppeen (kaksivaihejäädytys). Nämä menetelmät soveltuvat karaistuneen, lepotilassa olevan kasvinosan säilyttämiseen. Kaksivaihejäädytyksessä tarvitaan ohjelmoitavaa pakastinta lämpötilan hallittuun laskemiseen. Muut perinteiset menetelmät ovat tekniikaltaan yksinkertaisempia.

Vitrifikaatioon tai dehydraatioon perustuvia menetelmiä käyttäen on viime vuosina saatu hyviä tuloksia mikrolisätyn kasvimateriaalin, kuten versonkärkien ja somaattisten alkioiden, jäädyttämisessä. Vitrifikaatiopohjaisten menetelmien vaatimuksena on mikrolisäysmenetelmän toimiminen säilytettävälle 
kasville. Vitrifikaatio-menetelmässä (Sakai \& Kobayashi 1990) kasvimateriaalia käsitellään ensin väkevällä jäänsuoja-aineliuoksella ja aineisto upotetaan lopuksi nestetyppeen. Herkillä mikrolisäysmateriaaleilla on mahdollista päästä hyviin säilytystuloksiin kapselointimenetelmien avulla. Kapselointi-dehydraatiomenetelmässä (Fabre \& Dereuddre 1990) kasvimateriaali ensin kapseloidaan alginaatin ja kalsiumkloridin avulla. Tämän jälkeen kapselia kuivatetaan ilmavirrassa ennen siirtoa nestetyppeen. Kapselointi-vitrifikaatiomenetelmässä (Matsumoto ym. 1995) kasvimateriaali kapseloidaan ja kuivatetaan sitten vitrifikaatioliuoksen avulla.Käytännössä kylmäsäilytys muodostuu työketjusta, jonka vaiheista joko osa tai kaikki sisältyvät sekä perinteisiin että vitrifikaatiomenetelmiin riippuen kasvilajista ja -materiaalista.

Kryosäilytyksen vaiheet ovat 1) säilytettävän kasviaineiston esikäsittelyt, 2) jäädytys ja varastointivaihe sekä 3) kylmäsäilytetyn aineiston elvytys. Säilytettävän kasviaineiston esikäsittelyihin kuuluvat sekä mahdolliset emokasvien esikäsittelyt (esim. solukkoviljelmien kasvatus viileässä) että varsinaisten tallennettavien kasvinosien (esim versonkärjet tai silmut) eristys emokasvista ja niiden esikäsittelyt (esim. silmujen kasvatus sokerialustoilla) ja jäänsuoja-aineiden lisääminen. Varsinainen jäädytys voi tapahtua joko yksivaihejäädytyksenä tai asteittaisena jäädytyksenä. Kylmäsäilytysvaiheen jälkeiseen aineiston elvytykseen kuuluvat sulatus ja mahdollisesti jäänsuoja-aineiden poisto (vitrifikaatiomenetelmässä) tai rehydraatio(dehydraatio-menetelmissä) sekä sulatuksen jälkeinen kasvatus ja kasvuunlähdön mittaus.

MTT:ssa, Kasvintuotannon tutkimuksessa Laukaassa käytetään uusimpia bioteknisiä kylmäsäilytysmenetelmiä, jotka perustuvat solukkoviljelyllä tuotettujen silmujen tai versonkärkien säilytykseen. Tällä hetkellä käynnissä olevassa hankkeessa keskitytään erityisesti solukkoviljeltyjen aineistojen kryosäilytykseen vitrifikaatiomenetelmin. Vitrifikaatiossa eristettyjen kasvupisteiden soluissa oleva vesi vaihdetaan jäänsuoja-aineisiin käsittelemällä niitä vitrifikaatioliuoksin. Tällöin solujen ja soluvälien neste muuttuu niin viskoosiseksi, että kidemäistä jäätä ei synny. Esikäsittelyjen jälkeen solukkoviljelty kasvimateriaali jäädytetään.

Menetelmän valinnassa mallikasveina käytettiin aluksi vadelmaa, hapankirsikkaa, luumua ja omenaa. Menetelmäkokeilujen jälkeen Laukaassa otettiin käyttöön muunneltu pisara-vitrifikaatiomenetelmä, joka optimoitiin ensin vadelmalle ja mansikalle. Menetelmä soveltuu solukkoviljellylle materiaalille ja siinä käytetään yksivaihejäädytysmenetelmää. Se on ilmeisesti optimoitavissa laajasti eri kasvullisesti lisättäville kasveille riippumatta niiden kylmäkaraistumiskyvystä.

Laukaan pisara-vitrifikaatiossa jäädytys tapahtuu asettamalla kasvupisteet steriilisti folioliuskan päälle pieneen pisaraan vitrifikaatioliuosta ja sulkemalla folioliuska pieneen putkeen, joka upotetaan suoraan nestemäiseen typpeen. Jäädytyksen jälkeen putket siirretään säilytykseen kryotankkiin. Halutun säilytysajan jälkeen kasvupisteet sulatetaan $+40^{\circ} \mathrm{C}$ :een vesihauteessa. Tämän jälkeen jäänsuoja-aineet pestään pois ja versonkärjet siirretään kasvamaan ravintoalustalle. Kryokäsittelyn jälkeistä aineiston eloonjäämistä, kasvuunlähtöä ja aineistosta toipuvien viljelmien määrää havainnoidaan useiden kuukausien ajan.

\section{Tulokset ja tulosten tarkastelu}

Vuonna 2006 käynnistyneen tutkimushankken myötä MTT:een on perustettu pysyvä kylmäsäilytyskokoelma eli kryopankki, johon kerätään säilytyksen kannalta arvokkaiksi todettuja geenivaroja. Kryopankin pitkäaikaiskokoelma toimii ensisijaisena duplikaattina kenttä- ja in vitro kokoelmille. Pitkäaikaiskokoelman lisäksi kryotankkiin voidaan tallentaa geenivaroja myös ns. aktiiviseksi kokoelmaksi esimerkiksi MTT:n omaa käyttötarvetta varten. Kryopankin aktiivisesta kokoelmasta kasvimateriaalia voidaan elvyttää aina tarvittaessa tutkimus- ja jalostuskäyttöön sekä ydinkasvihuoltoa ja valiotaimituotantoa varten.

Kansallisten geenivarojen pikäaikaissäilytys kryopankkiin on aloitettu tallettamalla kasvigeenivaraohjelman humalakokoelmaa sekä MTT Piikkiön vadelmakokoelmaa. Työ on käynnissä myös mm. mansikoilla, herukoilla ja Prunus-lajeilla. Perunan kryosäilytys on kokeiluasteella. Perunan kansallisten aineistojen säilyttämisen kannalta kryotekniikkaan perustuva pitkäaikaissäilytysmenetelmän kehittäminen olisi tärkeää, koska NGB:llä ei ole olemassa peruna-aineistosta duplikaattikokoelmaa. Kiireisiä säilytykseen otettavia kokoelmia ovat tällä hetkellä mm. NGB:n Prunus-kokoelma, joka aiemmin sijaitsi Hämeen tutkimusasemalla. Aineistosta on otettu mikrolisäysaloitukset myöhempää kryosäilytystä varten. Aluksi viljelmiä väliaikaissäilytetään solukkoviljelminä, kunnes kryosäilytysmenetelmä on 
optimoitu Prunus-lajeille ja varsinaiseen pitkäaikaissäilytykseen voidaan ryhtyä. Helsingin yliopistolta poistetusta vadelmakokoelmasta ja Ruukin tutkimusasemalta poistetusta tyrnikokoelmasta on myös otettu talteen kantoja, jotka on jatkossa tarkoitus tallettaa kryopankkiin. Taulukossa 1 . on esitetty kasvilajikohtaisesti kuinka monella eri kannalla menetelmää on testattu sekä Laukaan kryopankkiin tähän mennessä tallennettujen kasvikantojen lukumäärät.

Varsinaisten kylmäsäilytysmenetelmien kuten erilaisten esikäsittelyiden ja käsittelyaikojen optimoinnin lisäksi kryosäilytyksen onnistuminen edellyttää kylmäsäilytyksen jälkeisten kasvuunlähtöolosuhteiden kehittämistä. Useimmilla lajeilla vaaditaan toipumisalustana käytettävän ravintoalustan optimoimista, jotta kryosäilytyksen jälkeinen kasvuunlähtö saadaan onnistumaan. Laukaassa tehtyjen havaintojen perusteella kasvin oma kasvihormonituotanto on tekijä, joka vaikuttaa kylmäsäilytyksestä siirrettyjen kasvupisteiden regeneroitumiseen toipumisalustalla.

Taulukko 1. Kryomenetelmäkokeilujen piiriin otettujen ja jo tankkiin talletettujen kantojen määrät lajeittain.

\begin{tabular}{lcc}
\hline Kasvilaji & $\begin{array}{l}\text { Kannat, joilla } \\
\text { kryosäilytysmenetelmää on jo } \\
\text { testattu Laukaassa } \\
(\mathbf{l k m})\end{array}$ & $\begin{array}{l}\text { Kannat, jotka ovat jo } \\
\text { pitkäaikaissäilytyksessä } \\
\text { kryomenetelmällä } \\
\text { (lkm) }\end{array}$ \\
\hline Vadelmat & 29 & 17 \\
Mansikat & 10 & 5 \\
Luumut & 5 & - \\
Kirsikat & 3 & - \\
Herukat & 3 & 1 \\
Humalat & 11 & - \\
Syreenit & 1 & - \\
Ruusut & 2 & - \\
Omenat & 1 & - \\
Lakka & 1 & - \\
Perunat & 10 & - \\
Yhteensä & $\mathbf{7 6}$ & $\mathbf{2 3}$ \\
\hline
\end{tabular}

\section{Johtopäätökset}

Kryosäilytys on potentiaalinen menetelmä erityisesti arvokkaiden kasvigeenivara-aineistojen pitkäaikaissäilytykseen. Puhdistettua aineistoa kuten Laukaan ydinkasvipankin kasveja voidaan säilyttää myös kasvullisesti solukkoviljelminä, mutta ylläpito on työlästä ja pidempiaikainen solukkoviljely voi aiheuttaa ainakin teoriassa geneettisen muuntelun riskin. Toimivat kryosäilytysmenetelmät antaisivat mahdollisuuden säilyttää MTT:n mittavia puutarhakasvien ja perunan aineistoja hyvin pitkiä aikoja ilman riskejä liittyen niiden menettämiseen tai saastumiseen taudeilla. Aineistojen tallentaminen Laukaan kryopankkiin edellyttää kuitenkin kunkin kasvilajin kohdalla toimivaa mikrolisäysmenetelmän ja kryosäilytysmenetelmän olemassaoloa. Vaikka Laukaassa kehitetty pisara-vitrifikaatiomenetelmä tuntuu olevan käytettävissä laajasti useille kasvullisesti lisättäville kasveille vaatii sen käyttöönotto kuitenkin kunkin kasvilajin kohdalla menetelmän soveltuvuuden testausta ja tarvittaessa optimointia ennen varsinaista pitkäaikaissäilytykseen tähtäävää tallennustyötä.

\section{Kirjallisuus}

Fabre, J. \& Dereuddre, J. 1990. Encapsulation-dehydration: a new approach to cryopreservation of Solanum shoot tips. Cryo-letters 11: 413-426.

Forsline, P.L. 2000. Procedures for collection, conservation, evaluation and documentation of Malus germplasm. Acta Hort. 522: 223-234.

Matsumoto, T., Sakai, A., Takahashi, C. \& Yamada, K. 1995. Cryopreservation of in vitro-grown apical meristems of wasabi (Wasabia japonica) by encapsulation-vitrification method. CryoLetters 16: 189-196.

Reed, B.M., Engelmann, F., Dulloo, M.E. \& Engels, J.M.M. 2004. Technical quidelines for the management of field and in vitro germplasm collections. IPGRI Handbooks for Genebanks No. 7. International Plant Genetic Resources Institute, Rome, Italy. $106 \mathrm{~s}$.

Sakai, A. \& Kobayashi, S. 1990. A simple and efficient procedure for cryopreservation of nucellar cells of navel orange by vitrification. Cryobiology 27: 657 . 